\title{
Unraveling the Interaction between Arbuscular Mycorrhizal Fungi and Camellia Plants
}

\author{
Rui-Cheng Liu ${ }^{1}$, Zhi-Yan Xiao ${ }^{2}$, Abeer Hashem ${ }^{3}$, Elsayed Fathi Abd_Allah ${ }^{4} \oplus$, Yong-Jie Xu ${ }^{5}$ \\ and Qiang-Sheng $\mathrm{Wu}$ 1,*(D) \\ 1 College of Horticulture and Gardening, Yangtze University, Jingzhou 434025, China; \\ 202072809@yangtzeu.edu.cn \\ 2 Wuhan Forestry Workstation, Wuhan 430023, China; xzhyan@163.com \\ 3 Botany and Microbiology Department, College of Science, King Saud University, P.O. Box. 2460, \\ Riyadh 11451, Saudi Arabia; habeer@ksu.edu.sa \\ 4 Plant Production Department, College of Food and Agricultural Sciences, King Saud University, \\ P.O. Box. 2460, Riyadh 11451, Saudi Arabia; eabdallah@ksu.edu.sa \\ 5 Hubei Academy of Forestry, Wuhan 430075, China; xuyongjie2007@163.com \\ * Correspondence: wuqiangsheng@yangtzeu.edu.cn
}

check for updates

Citation: Liu, R.-C.; Xiao, Z.-Y.; Hashem, A.; Abd_Allah, E.F.; Xu, Y.-J.; $\mathrm{Wu}, \mathrm{Q}$.-S. Unraveling the Interaction between Arbuscular Mycorrhizal Fungi and Camellia Plants. Horticulturae 2021, 7, 322. https:// doi.org/10.3390/horticulturae7090322

Academic Editor: Stefano Ghignone

Received: 28 August 2021

Accepted: 14 September 2021

Published: 17 September 2021

Publisher's Note: MDPI stays neutral with regard to jurisdictional claims in published maps and institutional affiliations.

Copyright: (c) 2021 by the authors. Licensee MDPI, Basel, Switzerland. This article is an open access article distributed under the terms and conditions of the Creative Commons Attribution (CC BY) license (https:/ / creativecommons.org/licenses/by/ $4.0 /)$.

\begin{abstract}
Camellia is a genus of evergreen shrubs or trees, such as C. japonica, C. sinensis, C. oleifera, etc. A group of beneficial soil microorganisms, arbuscular mycorrhizal fungi (AMF), inhabit the rhizosphere of these Camellia spp. A total of eight genera of Acaulospora, Entrophospora, Funneliformis, Gigaspora, Glomus, Pacispora, Scutellospora, and Sclerocystis were found to be associated with Camellia plants with Glomus and/or Acaulospora being most abundant. These mycorrhizal fungi can colonize the roots of Camellia spp. and thus form arbuscular mycorrhizal symbionts. AMF is an important partner of Camellia spp. in the field of physiological activities. Studies indicated that AMF inoculation has been shown to promote plant growth, improve nutrient acquisition and nutritional quality, and increase resistance to drought, salinity and heavy metal contamination in potted Camellia. This review thus provides a comprehensive overview of AMF species occurring in the rhizosphere of Camellia spp. and summarizes the variation in root AMF colonization rate as well as the environmental factors and soil nutrients affecting root colonization. The paper also reviews the effects of AMF on plant growth response, nutrient acquisition, food quality, and stress tolerance of Camellia spp.
\end{abstract}

Keywords: diversity; mycorrhizas; symbiosis; tea

\section{Introduction}

Arbuscular mycorrhizal fungi (AMF) are widely found in various soils [1]. AMF colonize roots of about $80 \%$ of vascular plants and thus form arbuscular mycorrhizas in host roots [2]. AMF promote plant growth, increase mineral element absorption, and improve plant stress tolerance [3-5]. AMF absorb more water for the host through the extraradical hyphae [6,7], and also secrete glomalin into the soil (defined as glomalinrelated soil protein) to cement soil aggregates and improve soil moisture-holding capacity and permeability [8]. In addition, AMF can mitigate the toxicity of heavy metals by competitive uptake of heavy metal ions from the soil $[9,10]$, as well as improve the soil environment $[3,4,11,12]$.

Camellia is a genus of evergreen shrubs or trees in the Camelliaceae family, which is mainly concentrated in eastern and southeastern Asia [13]. Camellia is mainly composed of Camellia sinensis (one of the three major beverages in the world), C. oleifera (an oil seed crop), and C. japonica with ornamental value. C. sinensis grows in acidic soil [14,15], where a certain amount of AMF communities are inhabited in their rhizosphere [16]. In natural fields, AMF colonization frequency and colonization rate of tea trees are $7.3-86.7 \%$ and $0.8-32.7 \%$, respectively, with large variation among varieties [17]. AMF have an impact on 
tea growth and nutrient absorption [18]. C. oleifera is a small evergreen tree and its seeds contain high-quality edible oils $[19,20]$, along with abundant AMF communities in the rhizosphere [21]. C. japonica is an excellent tree species for urban and rural greening [22,23]. In this paper, we review the diversity AMF of Camellia plants and their impacts on plants, with a view to provide the reference for the screening of dominant AMF strains for their production and application.

\section{AMF Diversity in Rhizosphere of Camellia spp.}

\subsection{Morphological Identification}

AMF diversity of Camellia spp. has been reported, based on morphological identification (Table 1). Tunstall [24] first identified arbuscular mycorrhizas from the roots of C. sinensis. In India, Singh et al. [25] conducted morphological identification of AMF diversity in "natural" and "cultivated" tea trees in Uttaranchal Himalaya and found 51 AMF species belonging to four genera, including Glomus, Gigaspora, Acaulospora and Scutellospora, of which 21 species were identified, with Glomus as the dominant genus. Gupta and Sharma [26] isolated six AMF species from four tea districts of Dehradun based on their morphology, and three identified AMF species belonged to Glomus. Sharma et al. [27] identified Acaulospora, Glomus, and Gigaspora in four tea plantations in Dehradun Himalaya (India), with the dominant genera being Glomus and Acaulospora. In China, Lu and Wu [28] identified 12 AMF species in tea plantations in the southern region of Henan province, belonging to Acaulospora, Glomus, Gigaspora, and Scutellospora, of which the dominant genera are Acaulospora and Glomus. Wu et al. [29] isolated $22 \mathrm{AMF}$ species of three genera in the tea of Qingdao, including 13 species of Acaulospra, 8 species of Glomus and 1 species of Gigaspora, and the relative abundance of Glomus and Acaulospra was higher than that of other genera. In ten regions of Guizhou with five tree varieties, Xing et al. [30] identified 31 species of AMF belonging to four genera, including 18 species of Glomus, 9 species of Acaulospora, 3 species of Gigaspora and 1 species of Entrophospora, with the dominant genera Glomus and Acaulospora. Due to the large geographical difference between China and India, the growth environment of tea is quite different, but the dominant genera of AMF in tea in the two countries are similar, both of which are Glomus and Acaulospora. AMF community in C. oleifera was studied by Chinese scholars only. In Hunan province, Deng et al. [31] identified eight AMF species, belonging to Glomus, Acaulospora, and Scutellospora, with Glomus as the dominant genus. 
Table 1. AMF diversity of Camellia plants.

\begin{tabular}{|c|c|c|c|c|c|}
\hline Camellia Plants & $\begin{array}{l}\text { Sampling } \\
\text { Regions }\end{array}$ & Identification Method & Identified Genena of AMF & Dominant Genus of AMF & Reference \\
\hline \multirow{5}{*}{ C. sinensis } & Uttaranchal Himalaya (India) & Morphology & Acaulospora; Gigaspora; Glomus; Scutellospora & Glomus & [25] \\
\hline & Dehradun District (India) & Morphology & Glomus & Glomus & [26] \\
\hline & Dehradun Himalaya (India) & Morphology & Acaulospora; Glomus; Gigaspora & Acaulospora and Glomus & [27] \\
\hline & Henan (China) & Morphology & Acaulospora; Gigaspora; Glomus; Scutellospora & Acaulospora and Glomus & [28] \\
\hline & Qingdao (China) & Morphology & Acaulospra; Gigaspora; Glomus & Acaulospra and Glomus & [29] \\
\hline \multirow{4}{*}{ C. oleifera } & Hunan (China) & Morphology & Acaulospora; Glomus; Scutellospora & Glomus & [31] \\
\hline & Wuhan (China) & $\begin{array}{l}\text { High-throughput sequencing } \\
\text { of } 18 \mathrm{~S} \text { rRNA gene }\end{array}$ & $\begin{array}{l}\text { Acaulospora; Ambispora; Archaeospora; } \\
\text { Claroideoglomus; Diversispora; Gigaspora; Glomus; } \\
\text { Paraglomus; Redeckera; Scutellospora }\end{array}$ & Glomus & [21] \\
\hline & Jiangxi (China) & $\begin{array}{l}\text { High-throughput sequencing } \\
\text { of } 18 \mathrm{~S} \text { rRNA gene }\end{array}$ & $\begin{array}{l}\text { Acaulospora; Ambispora; Archaeospora; } \\
\text { Claroideoglomus; Diversispora; Geosiphon; } \\
\text { Gigaspora; Glomus; Pacispora; Paraglomus; } \\
\text { Scutellospora; Septoglomus }\end{array}$ & Glomus & [32] \\
\hline & Guiyang (China) & $\begin{array}{l}\text { High-throughput sequencing } \\
\text { of } 18 \mathrm{~S} \text { rRNA gene }\end{array}$ & $\begin{array}{l}\text { Acaulospora; Archaeospora; Claroideoglomus; } \\
\text { Diversispora; Glomus; Paraglomus }\end{array}$ & Glomus & {$[33]$} \\
\hline \multirow{4}{*}{ C. japonica } & Fanjing Mountain (China) & Morphology & $\begin{array}{l}\text { Acaulospora; Funneliformis; Glomus; } \\
\text { Pacispora; Scutellospora; }\end{array}$ & Glomus & [34] \\
\hline & Chongqing (China) & Morphology & Acaulospora; Gigaspora; Glomus; Scutellospora & Acaulospora and Glomus & [35] \\
\hline & Shimane prefecture (Japan) & $\begin{array}{l}\text { High-throughput sequencing } \\
\text { of } 18 \mathrm{~S} \text { rRNA gene }\end{array}$ & $\begin{array}{l}\text { Acaulospora; Ambispora; Archaeospora; } \\
\text { Claroideoglomus; Diversispora; Funneliformis; } \\
\text { Geosiphon; Gigaspora; Glomus; Paraglomus; } \\
\text { Redeckera; Rhizophagus; Scutellospora }\end{array}$ & Glomus and Rhizophagus & [23] \\
\hline & Diankwan Island (Korea) & $\begin{array}{l}\text { High-throughput sequencing } \\
\text { of } 18 S \text { rRNA gene }\end{array}$ & $\begin{array}{l}\text { Acaulospora; Ambispora; Claroideoglomus; Glomus; } \\
\text { Rhizophagus; Scutellospora }\end{array}$ & Acaulospora and Rhizophagus & [36] \\
\hline
\end{tabular}


AMF population diversity of $C$. japonica was rarely reported, relative to $C$. sinensis and C. oleifera. A total of five genera and nine species of AMF were isolated from the rhizosphere of C. japonica forests in the Fanjing Mountains [34], including Acaulospora, Glomus, Scutellospora, Pacispora and Funneliformis, with the dominant genus being Glomus. He [35] conducted an AMF diversity study on the rhizosphere of $C$. japonica in Nanshan Botanical Garden, Chongqing, and found five species of Acaulospora, two species of Gigaspora, ten species of Glomus and one species of Scutellospora, with a total of four genera and 18 species, of which the dominant genera were Glomus and Acaulospora.

In short, a total of eight genera of Glomus, Gigaspora, Acaulospora, Scutellospora, Entrophospora, Sclerocystis, Pacispor and Funneliformis were found in the genus Camellia by morphological identification, with the dominant genera being Glomus and/or Acaulospora. The AMF resources of Camellia spp. are relatively abundant, but few genera of AMF were detected in these studies because the spore isolation of AMF is accidental. However, some studies have shown that AMF diversity in roots is relatively higher than in rhizosphere soil [21,37]. Morphological identification is inconsistent, limited, and contingent [38], which completely depends on the identifier's own knowledge and discrimination of AMF genera species [39].

\subsection{Molecular Identification}

Relative to morphological identification, molecular identification of AMF displayed different numbers of AMF species in the root and rhizosphere of C. oleifera. Liu et al. [21] analyzed the AMF community in roots and rhizosphere of C. oleifera grown in Wuhan (China) through high-throughput sequencing of $18 \mathrm{~S}$ rRNA, and detected 411 and 351 OTUs of AMF, respectively, a total of 467 OTUs, belonging to 10 genera and 138 species, of which Glomus was dominant (>86\%), and the rest Paraglomus, Claroidoglomus, Diversispora, Ambispora, Acaulospora, Archaeospora, Gigaspora, Redeckera and Scutellospora were lower. In the rhizosphere of five cultivated varieties of C. oleifera in Jiangxi, Lin et al. [32] identified 2538 OTUs, based on high-throughput Illumina sequencing of $18 \mathrm{~S}$ rRNA, belonging to 1 phylum, 1 class, 4 orders, 10 families and 12 genera, with Glomus as the dominant genus. Zhou et al. [33] found 58 OTUs of AMF in the rhizosphere of C. oleifera in Guiyang (China) through high-throughput Illumina sequencing of $18 \mathrm{~S}$ rRNA, belonging to 42 species in 6 genera (Glomus, Archaeospora, Claroidoglomus, Acaulospora, Paraglomus, and Diverspora) with Glomus as the dominant genus $(87.63 \%)$. In conclusion, the dominant genus of C. oleifera is still Glomus.

South Korean and Japanese researchers also sequenced the AMF community of C. japonica, and found more than 10 genera and more than 100 kinds of AMF. Berruti et al. [23] observed a total of 254 OTUs in C. japonica in Shimane (Japan), and the AMF diversity of the root (216 OTUs) was greater than that of the soil (125 OTUs), which was similar to the result of Liu et al. [21] in C. oleifera. Through the comparison of OTU sequences, the 254 OTUs were classified into 1 phyla, 1 class, 4 orders, 9 families, 13 genera (Rhizophagus, Glomus, Paraglomus, Scutellospora, Gigaspora, Claroidoglomus, Funeliformis, Diversipora, Acaulospora, Redeckera, Ambispora, Archaeospora, and Geosiphon), and the dominant genera were Rhizophagus and Glomus. Lee et al. [36] sampled the rhizosphere of C. japonica in Dian Guan Island, South Korea, isolated 248 spores of AMF, and conducted high-throughput sequencing of $18 \mathrm{~S}$ rRNA to obtain 11 species of AMF belonging to 6 genera, of which Acaulospora (49.60\%) and Rhizophagus (31.29\%) were the dominant genera, followed by Glomus (12.03\%), Scutellospora (4.09\%), Claroidoglomus (2.39\%) and Ambispora (0.58\%). The dominant AMF genera of $C$. japonica in Japan and South Korea are different, which may be caused by environmental factors, implying that AMF diversity shows regional distribution characteristics.

Based on molecular identification, Glomus, Paraglomus, Gigaspora, Archaeospora, Acaulospora, Ambispora, Scutellospora, Diversispora, Pacispora, Geosiphon, Septoglomus, Claroideoglomus, Rhizophagus, Funneliformis, and Redeckera were found in Camellia, and the detected AMF resources were more abundant than the morphological identification. 
The dominant genus, Glomus, was detected from the root and rhizosphere soil of C. oleifera, which was consistent with morphological identification. The dominant genera detected from C. japonica were Rhizophagus, Glomus and Acaulospora, which were higher than the dominant genera (Glomus and Acaulospora) previously identified by morphology, because molecular identification was more comprehensive [40,41].

\section{AMF Colonization of Camellia Plants and Its Influencing Factors}

\subsection{Root AMF Colonization of Camellia Plants}

AMF can colonize the roots of plants to form intraradical hyphae, which are denser and finer than the root [42]. Thus, mycorrhizal hyphae help host plants absorb more nutrients than non-mycorrhizal plants. Singh et al. [25] observed that AMF colonization in natural and planted tea plantations in India could be as high as $97.33 \%$ and $98.13 \%$ during the dormant stage. However, Morita and Konishi [43] observed an AMF colonization rate of only $17 \%$ in tea trees, and Gao et al. [17] revealed $7.01 \%$ of root mycorrhizal colonization rate in tea trees under open field, indicating relatively low root colonization. In Himalayas of India, AMF colonization (Figure 1a) was $62.29 \%, 55.68 \%, 33.10 \%$ and $63.36 \%$ in tea trees in four different areas [27]. In southern Henan (China), tea trees recorded $66.07 \%$ of root mycorrhizal colonization [28]. These results suggest that the root of the tea tree could be colonized by indigenous AMF. In tea, arbuscules are arum-type, and mycelium in roots is rare [17]. Interestingly, arbuscules are digested by the host cells and then changed into spongy structures [17]. Vesicles are sac-like structures formed by the apical expansion of the intraradical mycelium, mostly oval $(64-80 \times 112-128 \mu \mathrm{m})$, but also spherical in the shape [44]. When the cortex of the root is shed, the vesicles may also enter the soil with the root tissue and become a new infester and dormant spores.
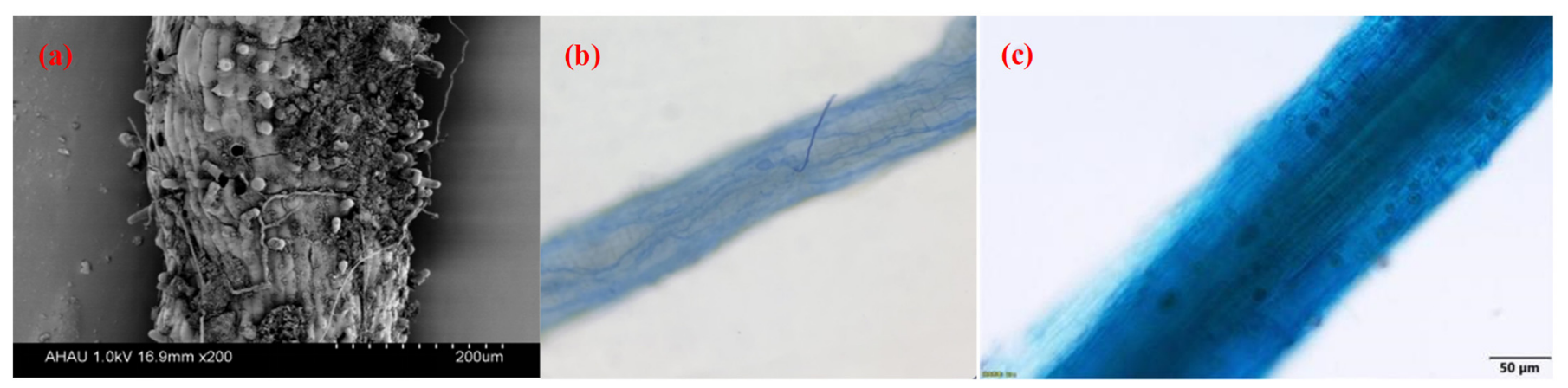

Figure 1. Root mycorrhizal colonization of Camellia spp. (a) mycorrhizal colonization in roots of Camellia sinensis; (b) mycorrhizal colonization in roots of $C$. oleifera; (c) mycorrhizal colonization in roots of $C$. japonica. These figures were derived from unpublished data by the authors.

However, AMF colonization (Figure 1b) in C. oleifera is relatively low, with $30.73-41.68 \%$ of AMF colonization in Wuhan (China) [21], which was close to the $20-42 \%$ of root colonization observed by Lin et al. [32] in Jiangxi (China). Mejstrik [45] found root mycorrhizal colonization of $C$. japonica in New Zealand, coupled with typical vesicles and arbuscules (Figure 1c). Later Borriello et al. [46] in Piedmont (Italy) observed 14.12\%, 32.55\%, and $9.92 \%$ of root AMF colonization in three regions. In short, Camellia spp. is colonized by indigenous AMF thus forming a symbiosis, but the degree of AMF colonization varies.

\subsection{Factors Affecting AMF Colonization}

\subsubsection{Seasonal Variations}

AMF diversity of plants varies with seasonal climate [47,48]. Sharma et al. [27] studied AMF colonization of tea plants in annual dynamic change and found that AMF colonization rates of tea trees varied drastically with seasonal changes, with the highest AMF infestation rates occurring in summer (rainy season). Their results were consistent with those of Chandra et al. [49], who observed that AMF activity in the soil was highest in summer, 
along with the highest spore numbers and colonization rates [50]. Similarly, Singh et al. [25] also pointed out seasonal changes in root AMF colonization of tea plants, followed by the highest colonization in summer.

\subsubsection{Soil Factors}

Root AMF colonization can be affected by levels of mineral elements in the soil [51]. The colonization rate of AMF on tea trees decreased significantly with the increase of soluble $\mathrm{P}$ application [52]. Soil $\mathrm{pH}$ value significantly affected the AMF community of tea trees, because most AMF species prefer to inhabit slightly acidic soils [53]. Among five soil factors ( $\mathrm{pH}$, hydrolytic $\mathrm{N}$, Olsen-P, available $\mathrm{K}$ and organic matter), the root AMF rate of tea trees was significantly more influenced by soil organic matter content than by available K and Olsen-P [17]. In C. oleifera, root AMF colonization was significantly and positively correlated with soil ammonium nitrogen and available potassium, but negatively correlated with soil $\mathrm{pH}$ value [21]. In C. japonica, soil mineral elements like $\mathrm{N}, \mathrm{P}, \mathrm{K}$, and $\mathrm{Mg}$ are associated with root mycorrhizal development [23,47]. The excess of soil mineral elements such as $\mathrm{N}$ and $\mathrm{P}$ negatively affects the growth of mycorrhizal mycelium [54], and soil $\mathrm{pH}$ value is even more directly affecting AMF diversity [40]. Thus, soil physico-chemical properties strongly affect AMF colonization in Camellia plants [34].

\section{AMF Diversity in Rhizosphere of Camellia spp.}

AMF in the soil colonize the roots of Camellia spp. and confer many benefits to the host plants, such as improved food quality, increased resistance, accelerated nutrient acquisition, and improved plant growth, as detailed in Table 2.

Table 2. Roles of AMF fungi in Camellia plants.

\begin{tabular}{|c|c|c|c|}
\hline $\begin{array}{l}\text { Camellia } \\
\text { Plants }\end{array}$ & Mycorrhizal Fungi & Mycorrhizal Effects on Camellia Plants & Reference \\
\hline \multirow{9}{*}{$\begin{array}{l}\text { Camellia } \\
\text { sinensis }\end{array}$} & $\begin{array}{l}\text { Acauospora scrobiculata, Glomus aggregatum, } \\
\text { G. fasciculatum, G. geosporum, G. intraradices, and } \\
\text { Scutellospora calospora }\end{array}$ & biomass $\uparrow$ & [6] \\
\hline & $\begin{array}{l}\text { Ac. spinosa, Ac. sp. 1, G. aggregatum, G. ambisporum, } \\
\text { G. clavisporum, } \\
\text { G. geosporum, G. mosseae, G. pustulatum, } \\
\text { and Glomus sp. }\end{array}$ & leaf sugar $\uparrow$; amino acids $\uparrow$; proteins $\uparrow$ & [15] \\
\hline & $\begin{array}{l}\text { Claroideoglomus etunicatum, Diversispora spurca, } \\
\text { D. versiformis, and mixed-AMF }\end{array}$ & $\begin{array}{l}\text { stem diameter } \uparrow \text {; plant height } \uparrow \text {; leaf area } \uparrow \text {; bud } \\
\text { number } \uparrow \text {; root morphogenesis } \uparrow \text {; root-hair growth } \uparrow\end{array}$ & [18] \\
\hline & G. epigaeumg & $\begin{array}{l}\text { biomass } \uparrow \text {; mineral elements } \uparrow \text {; leaf } \mathrm{P}, \mathrm{Mg}, \mathrm{Fe}, \mathrm{Zn} \text {, and } \\
\mathrm{Cu} \uparrow \text {; chlorophyll } \uparrow \text {; soil phosphatase activity } \uparrow\end{array}$ & {$[55]$} \\
\hline & C. etunicatum under P stress & $\begin{array}{l}\text { root system architecture } \uparrow ; \text { root } \mathrm{P} \uparrow \text {; root acid } \\
\text { phosphatase in } P_{50} \uparrow ; \text { soil neutral and total phosphatase } \\
\uparrow ; C S P T 1 \uparrow ; C \text { CSPT4 } \downarrow\end{array}$ & {$[56]$} \\
\hline & G. intraradices under Pb stress & Biomass $\uparrow$; glomalin $\uparrow$; $\mathrm{Pb}$ in glomalin $\uparrow$ & [57] \\
\hline & G. versiforme under salt stress & $\begin{array}{l}\text { growth } \uparrow \text {; leaf and root } \mathrm{N}, \mathrm{P}, \mathrm{K}, \mathrm{Mg}, \mathrm{Fe} \text {, and } \mathrm{Zn} \uparrow \text {; water } \\
\text { saturation deficit } \downarrow\end{array}$ & [58] \\
\hline & Clariodeoglomus etunicatum under drought stress & leaf water content $\uparrow$; antioxidant enzyme activity $\uparrow$ & [59] \\
\hline & $\begin{array}{l}\text { G. intraradices, G. mosseae, and G. versiforme under } \\
\text { drought stress }\end{array}$ & $\begin{array}{l}\text { plant growth performance } \uparrow \text {; soluble protein } \uparrow \text {; proline } \\
\uparrow \text {; malondialdehyde } \downarrow \text {; superoxidase } \uparrow \text {; peroxidase } \uparrow \text {; } \\
\text { catalase } \uparrow \text {; glutathione } \uparrow\end{array}$ & {$[60]$} \\
\hline \multirow{3}{*}{$\begin{array}{l}\text { Camellia } \\
\text { oleifera }\end{array}$} & Funneliformis mosseae & total leaf area $\uparrow$; root length $\uparrow$; root average diameter $\uparrow$ & [61] \\
\hline & G. versiforme and G. mosseae & root biomass $\uparrow$; root $\mathrm{P} \uparrow$; leaf $\mathrm{N} \downarrow$ & [62] \\
\hline & G. intraradices, G. mosseae, and G. versiforme & $\begin{array}{l}\text { leaf water content } \uparrow \text {; stability of cell membrane } \uparrow \text {; } \\
\text { soluble sugar } \uparrow\end{array}$ & [63] \\
\hline $\begin{array}{l}\text { Camellia } \\
\text { japonica }\end{array}$ & F. mosseae & $\begin{array}{l}\text { number of flowers } \uparrow \text {; flower depth } \uparrow \text {; leaf size } \uparrow \text {; } \\
\text { chlorophyll } \uparrow ; \text { root } \mathrm{Ca}, \mathrm{Mg}, \mathrm{K}, \mathrm{Cu}, \mathrm{Mn}, \mathrm{Fe} \text {, and } \mathrm{Zn} \uparrow \text {; } \\
\text { leaf } \mathrm{Cu} \text { and } \mathrm{Mn} \uparrow\end{array}$ & [64] \\
\hline
\end{tabular}




\subsection{Plant Growth and Development}

AMF plays an important role in plant growth [65]. AMF inoculation in Camellia spp. affects its growth parameters, depending on the AMF strain (Figure 2). In tea, inoculation with Claroideoglomus etunicatum, Diversispora spurca, D. versiformis and mixed-AMF increased stem diameter, plant height, leaf area, and bud number, of which C. etunicatum displayed the highest effect [18]. In addition, AMF inoculation also significantly improved root morphogenesis of tea and promoted root-hair growth [18]. Karthikeyan et al. [6] studied the effects of six AMF species on the growth and development of tea and found that each species promoted the growth of tea, with Scutellospora calipers being the more efficient species than the other five AMF species. Funneliformis mosseae stimulated the increase in plant height, total leaf area, root length and root average diameter of $C$. oleifera [61]. Further, $F$. mosseae also increased the number of flowers, leaf size, and chlorophyll content of $C$. japonica, along with the increase in plant growth [64].

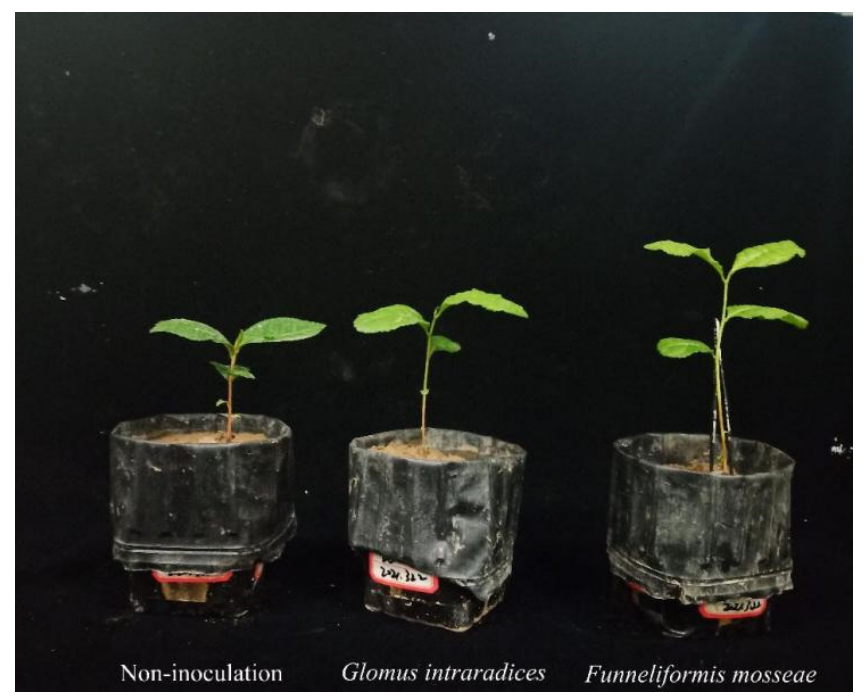

Figure 2. Plant growth performance of Camellia oleifera seedlings after two months of the inoculation with Funneliformis mosseae and Glomus intraradices (unpublished data by the authors).

\subsection{Nutrient Uptake}

AMF form extraradical mycelium in the soil, thus promoting nutrient uptake of the host plant [66]. In tea, AMF inoculation had significant and positive effects on leaf sugar, amino acids, and protein contents [15]. Shao et al. [67] found similar effects in tea treated with four AMF species. In addition to nutritional quality, AMF enhanced the uptake of mineral elements such as N, P, Mg and Fe in tea [55] and promoted photosynthesis in tea trees, thereby, increasing the production of photosynthates [68]. The P increase of tea under mycorrhization is due to the fact that AMF stimulated soil neutral and total phosphatase activity and up-regulated CSPT1 expression levels, independent on soil $\mathrm{P}$ levels [56]. However, in C. oleifera, two AMF species, Glomus versiforme and G. mosseae, greatly increased the root biomass and the $\mathrm{P}$ content of the whole plant, along with the decrease of $\mathrm{N}$ content [62]. Wu et al. [69] further observed that inoculation with Funneliformis mosseae increased soil acid phosphatase, alkaline phosphatase, and phytase activity, thus decomposing the organic $\mathrm{P}$ in the soil into inorganic $\mathrm{P}$, which is uptaken by plants. As a result, AMF enhance the mineralization of soil organic P. In addition, AMF also increased the content of mineral elements like $\mathrm{Ca}, \mathrm{Mg}, \mathrm{K}, \mathrm{Cu}, \mathrm{Mn}, \mathrm{Fe}$, and $\mathrm{Zn}$ in roots of $C$. japonica, as well as increased chlorophyll content and photosynthetic rate [64]. In conclusion, AMF significantly increased the mineral element content and nutrient quality of Camellia spp. 


\subsection{Stress Resistance}

AMF improve plant stress resistance by a serial of mechanisms including water absorption of mycorrhizal extraradical hyphae [70], improved root-hairs and root microenvironment, enhanced antioxidant defense systems, improved osmotic adjustment, and up-regulated stress gene expression $[4,7,71-74]$. In tea, AMF inoculation improved the uptake of mineral elements under salt stress and reduced the damage caused by $\mathrm{Pb}$ stress in tea [75]. Under Pb stress, AMF (e.g., G. intraradices) inoculation induced the accumulation of total glomalin-related soil protein in tea, whose cysteine-containing peptide chains bound $\mathrm{Pb}$, and could substantially increase the accumulation of $\mathrm{Pb}$ into the protein by $89.98 \%$, thus preventing the transport of heavy metals to plants [57]. Liu et al. [58] also found that inoculation of AMF alleviated the inhibition of tea plants under salt stress. Additionally, Clariodeoglomus etunicatum accelerated leaf water content of drought-stressed tea plants, along with higher antioxidant enzyme activity like catalase (CAT), superoxide dismutase (SOD), and peroxidase (POD) [59]. AMF also dramatically increased SOD, POD, and CAT activities of tea under soil moisture deficit conditions, coupled with the increase in soluble protein, proline, and glutathione and the decrease in superoxide anion radicals, hydrogen peroxide and malondialdehyde [60]. Inoculation with G. mosseae, G. versiforme, and G. intraradices increased leaf water content and the stability of cell membrane, and accelerated soluble sugar accumulation in C. oleifera subjected to soil moisture deficit conditions [63]. In addition to these physiological responses, little research has begun on the molecular level to uncover the response on the molecular level. Liu et al. [59] revealed higher expression levels of CSSOD and CsCAT in AMF-colonized tea seedlings versus non-AMF seedlings, irrespective of water status. Nevertheless, little research has been reported on the resistance of AMF to C. japonica.

\subsection{Food Quality}

Among Camellia plants, the tea plant is famous for its tea drinks and therefore the food quality of tea is important. AMF colonization can cause significant changes in the food quality of tea leaves. Soluble sugars, proteins, tea polyphenols, caffeine, free amino acids, flavonoids, and water leachate content were increased after inoculation with G. mosseae [63]. The increase in total amino acids under mycorrhization was associated with up-regulation of glatamine sythetase (CsGS), glutamine oxoglutarate aminotransferase (CsGOGAT), and glutamate dehydrogenase (CsGDH), and the increase in caffeine was related to upregulation of tea caffeine synthase 1 gene (CsTCS1) [67]. The positive effect of AMF on food quality of tea was also observed under drought stress and P stress [76-78]. Inoculation with Clariodeoglous etunicatum distinctly increased leaf sucrose, glucose, fructose, catechins, amino acids and tea polyphenols contents under soil adequate moisture and soil moisture deficit conditions [78]. This change is also associated with the expression of related genes under AMF regulation. For example, C. etunicatum-inoculated tea plants recorded higher expression levels of CsGDH, CsGOGAT, and 3-hydroxy-3-methylglutaryl coenzyme (CsHMGR) genes under soil drought than non-inoculated plants [77]. AMF colonization could promote the accumulation of amino acids in tea leaves by up-regulating the expression of CsGOGAT and thus activating the activity of GOGAT under soil drought, which further explains higher total amino acid content after AMF inoculation [77]. Overexpression of CsHMGR would improve crop quality by increasing terpene content. Under $\mathrm{P}$ stress condition, C. etunicatum accelerated total amino acids accumulation, coupled with higher expression of $\mathrm{Cs} G D H$; total flavonoid content was higher in mycorrhizal than nonmycorrhizal plants, together with induced expression of phenylalanine ammonia-lyase (CsPAL) and cinnamic acid 4-hydroxylase (CsC4H) [78]. However, the improvement of food quality by mycorrhization was different between different substrate P levels, suggesting differential regulated mechanisms. In short, AMF have positive effects on leaf food quality partly by means of up-regulation of relevant gene expression in tea plants. In addition, AMF inoculation could also increase the number and depth of flowers, and improve the quality of flowers [64]. 


\section{Conclusions}

There are many AMF populations in the rhizosphere of Camellia plants (Figure 3), which can colonize the root system and establish a symbiosis. These AMF species have shown positive benefits for Camellia spp. such as promoting plant growth and development, accelerating nutrient uptake, and enhancing stress resistance (Figure 3). Season and soil nutrient levels affect the root AMF colonization, spore number, and AMF diversity in the rhizosphere of Camellia spp. Compared with other mycorrhizal plants (e.g., citrus and maize), the study of AMF in Camellia spp. is still in the initial stage, and future studies on mycorrhizas of Camellia spp. need to focus on the following aspects:

(1) The rhizosphere of Camellia plants in open-field under non-AMF inoculation conditions has an AMF community based on morphological identification. Indigenous AMF colonizes roots of Camellia plants to form a symbiotic association. Due to the limitation of morphological identification, more work around high-throughput sequencing should be performed as much as possible to accurately identify the AMF community and provide a basis for screening of the suitable dominant strains for its application. In addition, future work needs to screen effective AMF strains in promoting plant growth of Camellia under non-sterilized soil conditions and in different soil types.

(2) Among Camellia plants, tea plants are rich in natural tea polyphenols, caffeine and other active ingredients; seeds of $C$. oleifera can be extracted as oil (tea oil) for consumption; the flower size, number and brightness of $C$. japonica (an ornamental plant) are important indicators for ornamental purposes. Earlier studies on AMF and Camellia plants focused on plant growth, nutrients and stress resistance. However, few studies have addressed the effects of AMF on functional constituents of tea and the oil yield and composition in the seeds of C. oleifera. The effects of AMF on the ornamental properties of $C$. japonica are also unknown. Future experiments should focus on the above aspects.

(3) AMF promote the absorption of nutrients (especially P) from the soil of Camellia plants, while the underlying mechanism is unknown. In addition, tea plants are typically grown in extremely acidic soil conditions where aluminum is relatively rich, resulting in aluminum stress in tea plants. Future work needs to revolve around whether and how AMF affects the aluminum tolerance of tea plants.

(4) In-depth study on the mechanism of AMF on enhancing stress tolerance of Camellia plants at physiological and molecular levels.

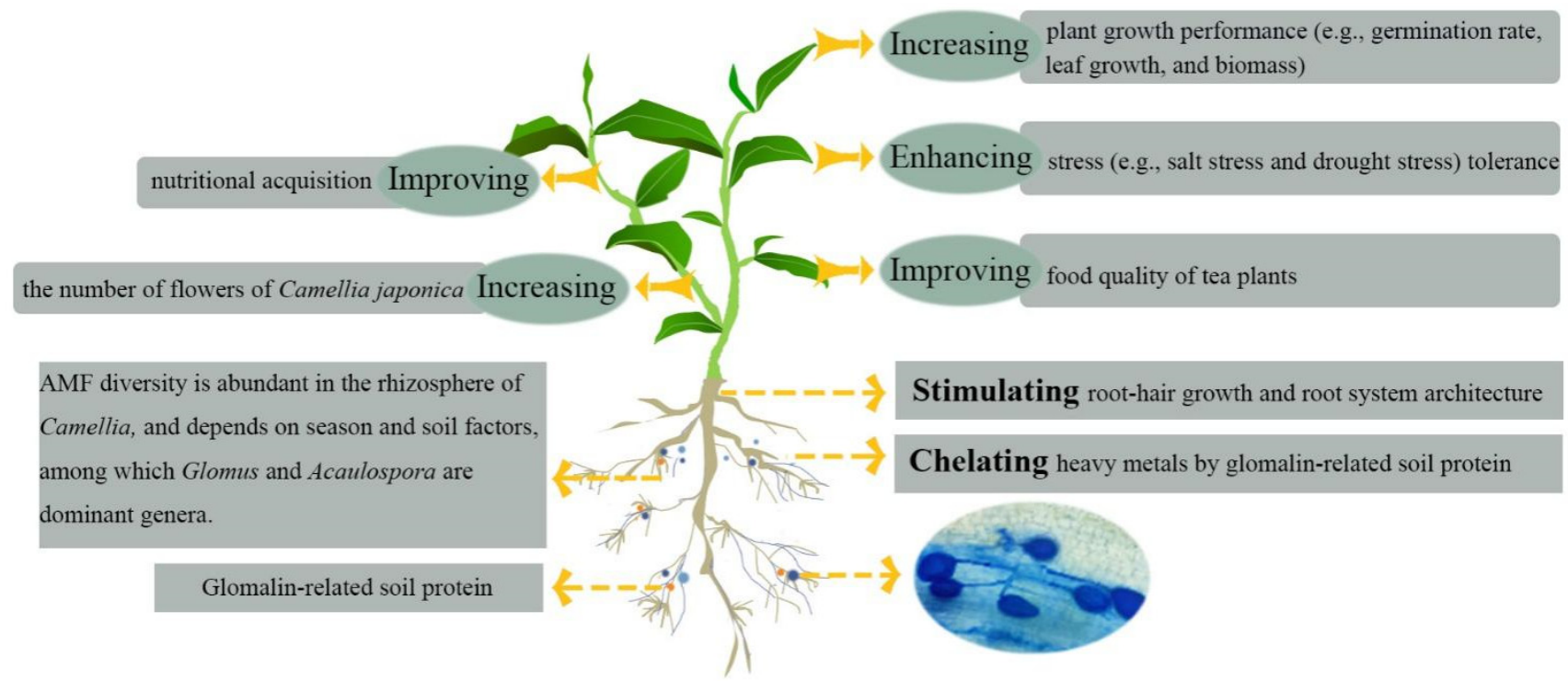

Figure 3. A diagram regarding mycorrhizal fungal roles in physiological activities of Camellia plants. 
Author Contributions: Conceptualization, R.-C.L. and Q.-S.W.; writing-original draft preparation, R.-C.L. and Q.-S.W.; writing-review and editing, A.H., E.F.A. and Q.-S.W.; supervision, A.H., Y.-J.X., Z.-Y.X., E.F.A. and Q.-S.W. All authors have read and agreed to the published version of the manuscript.

Funding: The authors thank Wuhan Forestry Workstation providing the funding to support the study. The authors would like to extend their sincere appreciation to the Deanship of Scientific Research at King Saud University for funding this research group NO (RGP-271).

Institutional Review Board Statement: Not applicable.

Informed Consent Statement: Not applicable.

Data Availability Statement: All the data supporting the findings of this study are included in this article.

Conflicts of Interest: The authors declare no conflict of interest.

\section{References}

1. Yang, L.; Zou, Y.N.; Tian, Z.H.; Wu, Q.S.; Kuča, K. Effects of beneficial endophytic fungal inoculants on plant growth and nutrient absorption of trifoliate orange seedlings. Sci. Hortic. 2021, 277, 109815. [CrossRef]

2. Meng, L.L.; He, J.D.; Zou, Y.N.; Wu, Q.S.; Kuča, K. Mycorrhiza-released glomalin-related soil protein fractions contribute to soil total nitrogen in trifoliate orange. Plant Soil Environ. 2020, 66, 183-189. [CrossRef]

3. Wu, Q.S.; Gao, W.Q.; Srivastava, A.K.; Zhang, F.; Zou, Y.N. Nutrient acquisition and fruit quality of Ponkan mandarin in response to AMF inoculation. Ind. J. Agric. Sci. 2020, 90, 1563-1567.

4. Zou, Y.N.; Zhang, F.; Srivastava, A.K.; Wu, Q.S.; Kuča, K. Arbuscular mycorrhizal fungi regulate polyamine homeostasis in roots of trifoliate orange for improved adaptation to soil moisture deficit stress. Front. Plant Sci. 2021, 11, 600792. [CrossRef]

5. Eid, K.E.; Abbas, M.H.H.; Mekawi, E.M.; EINagar, M.M.; Abdelhafez, A.A.; Amin, B.H.; Mohamed, I.; Ali, M.B. Arbuscular mycorrhiza and environmentally biochemicals enhance the nutritional status of Helianthus tuberosus and induce its resistance against Sclerotium rolfsii. Ecotox. Environ. Saf. 2019, 186, 109783. [CrossRef]

6. Karthikeyan, A.; Muthukumar, T.; Udaiyan, K. Response of tea (Camellia sinensis (L). Kuntze) to arbuscular mycorrhizal fungi under plantation nursery conditions. Biol. Agric. Hortic. 2005, 22, 305-319. [CrossRef]

7. Zhang, F.; Zou, Y.N.; Wu, Q.S. Quantitative estimation of water uptake by mycorrhizal extraradical hyphae in citrus under drought stress. Sci. Hortic. 2018, 229, 132-136. [CrossRef]

8. Wu, Q.S.; Srivastava, A.K.; Zou, Y.N. AMF-induced tolerant to drought stress in citrus: A review. Sci. Hortic. 2013, 164, 77-87. [CrossRef]

9. González-Chávez, M.C.; Carrillo-González, R.; Wright, S.F.; Nichols, K.A. The role of glomalin, a protein produced by arbuscular mycorrhizal fungi, in sequestering potentially toxic elements. Environ. Pollut. 2004, 130, 317-323. [CrossRef]

10. Cornejo, P.; Meier, S.; Borie, G.; Rillig, M.C.; Borie, F. Glomalin related soil protein in a Mediterranean ecosystem affected by a copper smelter and its contribution to $\mathrm{Cu}$ and Zn sequestration. Sci. Total Environ. 2008, 406, 154-160. [CrossRef]

11. He, J.D.; Chi, G.G.; Zou, Y.N.; Shu, B.; Wu, Q.S.; Srivastava, A.K.; Kuča, K. Contribution of glomalin-related soil proteins to soil organic carbon in trifoliate orange. Appl. Soil Ecol. 2020, 154, 103592. [CrossRef]

12. Cheng, H.Q.; Giri, B.; Wu, Q.S.; Zou, Y.N.; Kuča, K. Arbuscular mycorrhizal fungi mitigate drought stress in citrus by modulating root microenvironment. Arch. Agron. Soil Sci. 2021. [CrossRef]

13. Luo, C.Q.; Tan, X.F.; Ling, L.L. A Classification summary on plant of genus Camellia. J. Cent. South For. Univ. $1999,19,78-81$.

14. Mondal, T.K.; Bhattacharya, A.; Laxikumaran, M.; Ahuja, P.S. Recent advance of tea (Camellia sinensis) biotechnology. Plant Cell Tiss. Org. 2004, 76, 195-254. [CrossRef]

15. Singh, S.; Pandey, A.; Kumar, B.; Palni, L.M.S. Enhancement in growth and quality parameters of tea [Camellia sinensis (L.) O. Kuntze] through inoculation with arbuscular mycorrhizal fungi in an acid soil. Biol. Fert. Soils 2010, 46, 427-433. [CrossRef]

16. Lin, X.G.; Hao, W.Y. Mycorrhizal dependency of various kind of plants. Acta Bot. Sin. 1989, 31, 721-725.

17. Gao, X.B.; Chen, J.; Zhao, J.F.; Li, Z.; Guo, C.; Zhou, F.Y.; Wang, Z.X.; Tu, Y.Y.; Zhou, Y.F. Colonization characteristics of arbuscular mycorrhiza fungi in rhizosphere of local tea trees in Guizhou. Southwest China J. Agric. Sci. 2016, 29, 1328-1335.

18. Shao, Y.D.; Zhang, D.J.; Hu, X.C.; Wu, Q.S.; Jiang, C.J.; Xia, T.J.; Gao, X.B.; Kuča, K. Mycorrhiza-induced changes in root growth and nutrient absorption of tea plants. Plant Soil Environ. 2018, 64, 283-289.

19. Lee, C.P.; Shih, P.H.; Hsu, C.L.; Yen, G.C. Hepatoprotection of tea seed oil (camellia oleifera abel.) against $\mathrm{CCl}_{4}$-induced oxidative damage in rats. Food Chem. Toxicol. 2007, 45, 888-895. [CrossRef]

20. Zhang, Z.J.; Meng, J.X.; Pan, D.F.; Yang, C.; Li, Y. Mating system and progeny genetic diversity of camellia oleifera 'Ruan Zhi'. J. For. Res. 2019, 30, 267-272. [CrossRef]

21. Liu, R.C.; Xiao, Z.Y.; Hashem, A.; Abd_Allah, E.F.; Wu, Q.S. Mycorrhizal fungal diversity and its relationship with soil properties in Camellia oleifera. Agriculture 2021, 11, 470. [CrossRef] 
22. Hou, H.Y.; Duan, Y.P. Camellia japonica is in landscape afforestation medium disposition and application. Anhui Agri. Sci. Bull. 2009, 15, 76 .

23. Berruti, A.; Demasi, S.; Lumini, E.; Kobayashi, N.; Bianciotto, V.; Bianciotto, V. Wild Camellia japonica specimens in the Shimane prefecture (Japan) host previously undescribed AMF diversity. Appl. Soil Ecol. 2017, 115, 10-18. [CrossRef]

24. Tunstall, A.C. Mycorrhiza in tea plants. Quart. J. Indian Tea Assoc. Indian 1926, 159.

25. Singh, S.; Pandey, A.; Chaurasia, B.; Palni, L.M.S. Diversity of arbuscular mycorrhizal fungi associated with the rhizosphere of tea growing in 'natural' and 'cultivated' ecosites. Biol. Fert. Soils 2008, 44, 491-500. [CrossRef]

26. Gupta, R.K.; Sharma, C. Diversity of arbuscular mycorrhizal fungi in Camellia sinensis in Uttarakhand State, India. Afr. J. Biotechnol. 2013, 9, 5313-5319.

27. Sharma, C.; Gupta, R.K.; Pathak, R.K.; Choudhary, K.K. Seasonal colonization of arbuscular mycorrhiza fungi in the roots of Camellia sinensis (tea) in different tea gardens of India. ISRN Biodivers. 2015, 2013, 593086. [CrossRef]

28. Lu, D.S.; Wu, X.Q. Species of VAM fungi around tea roots in the southern area of Henan province. J. Nanjing For. Univ. 2005, 29, 33-36.

29. Wu, L.S.; Wang, Y.; Li, M.; Liu, R.J.; Ding, Z.T. A survey of arbuscular mycorrhizal fungi in the rhizosphere of Camellia sinensis in Laoshan. J. Qingdao Agric. Univ. 2009, 26, 171-173.

30. Xing, D.; Zhang, A.M.; Li, Z.; Chen, J.; Wang, Z.X.; Tu, Y.Y.; Gao, X.B. Resources and morphological characteristics of arbuscular mycorrhiza fungi around tea rhizosphere in Guizhou. Guizhou Agric. Sci. 2015, 43, 102-106.

31. Deng, X.J.; Zhou, G.Y.; Liu, J.A.; Li, L.; Bu, T.T. Diversity and community structure of arbuscular mycorrhizal fungi in Camellia oleifera stands in Hunan. J. Cent. South Univ. For. Tech. 2011, 31, 38-42.

32. Lin, Y.L.; Li, Z.Y.; Wu, F.; Pei, Y.; Zhang, Y.; Zhang, L.P.; Yang, T.; Tan, M.X. Community structure characteristics of arbuscular mycorrhizal fungi among Camellia oleifera cultivars. For. Res. 2020, 33, 163-169.

33. Zhou, G.R.; Shang, K.; Jiang, L. Diversity survey of AM fungi in rhizosphere soil of wild Camellia oleifera. J. Guizhou Univ. 2019, $36,26-31$.

34. Yuan, T.; Tao, G.Y.; Jiang, L. Arbuscular mycorrhizal fungi in the rhizospheric soil of four forest types in Fanjingshan national nature reserve. J. Northeast For. Univ. 2018, 46, 83-86.

35. He, W. AM Fungi Diversity in the Main Ornamental Gardens of Chongqing Nanshan Botanical Park. Master's Thesis, Southwest University, Chongqing, China, 2009.

36. Lee, E.H.; Ka, K.H.; Eom, A.H. Diversity of arbuscular mycorrhizal fungi in rhizospheres of Camellia japonica and neighboring plants inhabiting Wando of Korea. Korean J. Mycol. 2014, 42, 34-39. [CrossRef]

37. Wu, Q.S.; Srivastava, A.K. AMF diversity in citrus rhizosphere. Ind. J. Agric. Sci. 2017, 87, 653-659.

38. Gai, J.P.; Feng, G.; Li, X.L. Review of researches on biodiversity of arbusculay mycorrhizal fungi. Soils 2005, 37, $236-242$.

39. Yang, C.X.; Li, L.L. Research progress in arbuscular mycorrhizal fungi identification method application. Guizhou Agric. Sci. 2014, $42,93-97$.

40. Guo, X.H.; Gong, J. Differential effects of abiotic factors and host plant traits on diversity and community composition of root-colonizing arbuscular mycorrhizal fungi in a salt-stressed ecosystem. Mycorrhiza 2014, 24, 79-94. [CrossRef]

41. Yang, F.; Cao, J.M.; Chen, Y.Y.; Wang, J.L. Research progress on structure and identification method of arbusular mycorrhizal fungi. Mod. Agric. Sci. Tech. 2019, 17, 152-154+157.

42. Smith, S.E.; Smith, F.A. Roles of arbuscular mycorrhizas in plant nutrition and growth: New paradigms from cellular to ecosystem scales. Annu. Rev. Plant Biol. 2011, 62, 227-250. [CrossRef] [PubMed]

43. Morita, A.; Konishi, S. Relationship between vesicular-arbuscular mycorrhizal infection and soil phosphorus concentration in tea fields. Soil Sci. Plant Nutr. 1989, 35, 139-143. [CrossRef]

44. Ren, M.X.; Luo, Y.P. Advances in the study of VA mycorrhizae of tea trees. J. Tea 2005, 31, 28-31.

45. Mejstrik, V. The frequency of vesicular-arbuscular mycorrhizae in the roots of Camellia japonica L. from different sites in New Zealand. Pac. Sci. 1974, 28, 73-77.

46. Borriello, R.; Berruti, A.; Lumini, E.; Beffa, M.T.D.; Scariot, V.; Bianciotto, V. Edaphic factors trigger diverse AM fungal communities associated to exotic camellias in closely located Lake Maggiore (Italy) sites. Mycorrhiza 2015, 25, 253-265. [CrossRef]

47. Bencherif, K.; Boutekrabt, A.; Dalpé, Y.; Sahraoui, A.L.H. Soil and seasons affect arbuscular mycorrhizal fungi associated with Tamarix rhizosphere in arid and semi-arid steppes. Appl. Soil Ecol. 2016, 107, 182-190. [CrossRef]

48. Varela-Cervero, S.; López-García, A.; Barea, J.M.; Azcón-Aguilar, C. Spring to autumn changes in the arbuscular mycorrhizal fungal community composition in the different propagule types associated to a Mediterranean shrubland. Plant Soil 2016, 408, 1-14. [CrossRef]

49. Chandra, K.K.; Jamaluddin, A. Seasonal variation of VAM fungi in tree species planted in coalmine overbunden of Kusmunda (MP). J. Trop. For. 1998, 14, 118-123.

50. Gould, A.B.; Hendrix, J.W.; Ferriss, R.S. Relationship of mycorrhizal activity to time following reclamation of surface mine land in western Kentucky. I. Propagule and spore population densities. Can. J. Bot. 1996, 74, 247-261. [CrossRef]

51. Liang, S.M.; Zheng, F.L.; Abd_Allah, E.F.; Muthuramalingam, P.; Wu, Q.S.; Hashem, A. Spatial changes of arbuscular mycorrhizal fungi in peach and their correlation with soil properties. Soudi J. Biol. Sci. 2021. [CrossRef]

52. Lin, Z. Effect of VA mycorrhizal species on tea tree growth and absorption of mineral elements. J. Tea Sci. 1993, 13, 15-20. 
53. Pandey, A.; Palni, L.M.S. Bacillus species: The dominant bacteria of the rhizosphere of established tea bushes. Microbiol. Res. 1997, 152, 359-365. [CrossRef]

54. Avio, L.; Castaldini, M.; Fabiani, A.; Bedini, S.; Sbrana, C.; Turrini, A.; Giovannetti, M. Impact of nitrogen fertilization and soil tillage on arbuscular mycorrhizal fungal communities in a Mediterranean agroecosystem. Soil Biol. Biochem. 2013, 67, 285-294. [CrossRef]

55. He, S.L.; Liu, B.Y. Effect of VA mycorrhizal bacteria on tea tree mineral nutrition and its mechanism. J. Southwest Agric. Univ. 1994, 16, 492-496.

56. Shao, Y.D.; Hu, X.C.; Wu, Q.S.; Yang, T.Y.; Srivastava, A.K.; Zhang, D.J.; Gao, X.B.; Kuča, K. Mycorrhizas promote P acquisition of tea plants through changes in root morphology and P transporter gene expression. S. Afr. J. Bot. 2021, 137, 455-462. [CrossRef]

57. Chen, W.L.; Zhao, X.G.; Wang, H.; Yuan, Z.L. Effects of arbuscular mycorrhizal fungi (AMF) inoculation on detoxification capacity of tea tree under Pb stress. Henan Sci. 2014, 32, 511-515.

58. Liu, J.; Xiao, B.; Wang, L.X.; Li, J.; Pu, G.T.; Gao, T.; Liu, W. Influence of AM on the growth of tea plant and tea quality under salt stress. J. Tea Sci. 2013, 33, 140-146.

59. Liu, C.Y.; Wang, Y.J.; Wu, Q.S.; Yang, T.Y.; Kuča, K. Arbuscular mycorrhizal fungi improve the antioxidant capacity of tea (Camellia sinensis) seedlings under drought stress. Not. Bot. Horti Agrobot. 2020, 48, 1993-2005. [CrossRef]

60. Xu, P.H.; Wang, F.Q.; Qi, Y.G.; Zhang, F.; Yang, Q.; Xiao, B. Effect of arbuscular mycorrhizal fungi on drought resistance in tea plant (Camellia sinensis). Acta Agric. Bor. Occid. Sin. 2017, 26, 1033-1040.

61. Lin, Y.L.; Li, Z.Y.; Zhang, L.P.; Wu, F.; Yang, Y.; Tan, M.X.; Hu, D. Effects of organic phosphorus and AM fungi on growth, root morphology and photosynthetic characteristics of Camellia oleifera. Non-Wood For. Res. 2021, 39, 121-128.

62. Wang, D.X.; Chen, G.C.; Jiang, Z.P. Effects of arbuscular mycorrhiza on the growth and absorption of nitrogen and phosphorus in Camellia oleifera seedlings. Chin. For. Sci. Technol. 2010, 24, 23-26.

63. Wang, D.X.; Zhang, N.Y.; Chen, G.C. Effects of AM fungi on the growth and drought-resistance of Camellia oleifera. Guangxi For. Sci. 2011, 40, 259-261.

64. Berruti, A.; Borriello, R.; Beffa, M.; Scariot, V.; Bianciotto, V. Application of nonspecific commercial AMF inocula results in poor mycorrhization in Camellia japonica L. Symbiosis 2013, 61, 63-76. [CrossRef]

65. Selvakumar, G.; Shagol, C.C.; Kim, K.; Han, S.; Tongmin, S. Spore associated bacteria regulates maize $\operatorname{root} \mathrm{K}^{+} / \mathrm{Na}^{+}$ion homeostasis to promote salinity tolerance during arbuscular mycorrhizal symbiosis. BMC Plant Biol. 2018, 18, 109. [CrossRef] [PubMed]

66. Zou, Y.N.; Wu, Q.S.; Li, Y.; Huang, Y.M. Effects of arbuscular mycorrhizal fungi on root system morphology and sucrose and glucose contents of Poncirus trifoliata. Chin. J. Appl. Ecol. 2014, 25, 1125-1129.

67. Shao, Y.D.; Zhang, D.J.; Hu, X.C.; Wu, Q.S.; Jiang, C.J.; Gao, X.B.; Kuča, K. Arbuscular mycorrhiza improves leaf food quality of tea plants. Not. Bot. Horti Agrobo. 2019, 47, 608-614. [CrossRef]

68. Shu, J.L.; Li, M.J. Physiological effect of VA mycorrhizal study in tea tree. J. Tea Sci. 1987, 7, 7-14.

69. Wu, F.; Li, Z.; Lin, Y.; Zhang, L. Effects of Funneliformis mosseae on the utilization of organic phosphorus in Camellia oleifera Abel. Can. J. Microbiol. 2021, 67, 349-357. [CrossRef]

70. Huang, Y.F.; Wu, Q.L.; Wan, Q.; Shu, B. Research progress of arbuscular mycorrhizal fungi. Mod. Agric. 2019, 12, 9-12.

71. Zhang, F.; Wang, P.; Zou, Y.N.; Wu, Q.S.; Kuča, K. Effects of mycorrhizal fungi on root-hair growth and hormone levels of taproot and lateral roots in trifoliate orange under drought stress. Arch. Agron. Soil Sci. 2019, 65, 1316-1330. [CrossRef]

72. Cheng, H.Q.; Zou, Y.N.; Wu, Q.S.; Kuča, K. Arbuscular mycorrhizal fungi alleviate drought stress in trifoliate orange by regulating H+-ATPase activity and gene expression. Front. Plant Sci. 2021, 12, 659694. [CrossRef]

73. Cheng, X.F.; Wu, H.H.; Zou, Y.N.; Wu, Q.S.; Kuča, K. Mycorrhizal response strategies of trifoliate orange under well-watered, salt stress, and waterlogging stress by regulating leaf aquaporin expression. Plant Physiol. Biochem. 2021, 162, 27-35. [CrossRef] [PubMed]

74. Zou, Y.N.; Wu, Q.S.; Kuča, K. Unravelling the role of arbuscular mycorrhizal fungi in mitigating the oxidative burst of plants under drought stress. Plant Biol. 2021, 23, 50-57. [CrossRef] [PubMed]

75. Yang, Y.Z. Effects of arbuscular mycorrhizal fungi on growth and quality of tea under adversity stress. J. Green Sci. Technol. 2016, $18,127-128$.

76. Zhao, Q.H.; Sun, L.T.; Wang, Y.; Ding, Z.T.; Li, M. Effects of arbuscular mycorrhizal fungi and nitrogen regimes on plant growth, nutrient uptake and tea quality in Camellia sinensis (L.) O. Kuntze. Plant Physiol. J. 2014, 50, 164-170.

77. Wang, Y.J.; Gao, X.B.; Wu, Q.S.; Ji, D.B.; Cai, F.; Liu, C.Y. Influences of arbuscular mycorrhizal fungi on plant growth and tea quality of Fuding Dabaicha seedlings under different water conditions. J. Tea Sci. 2020, 40, 588-596.

78. Cao, J.L.; Shao, Y.D.; Zou, Y.N.; Wu, Q.S.; Yang, T.Y.; Kuča, K. Inoculation with Clariodeoglomus etunicatum improves leaf food quality of tea exposed to P stress. Not. Bot. Horti Agrobo. 2021, 49, 12166. [CrossRef] 